\title{
Systolic Anterior Motion Indicator
}

National Cancer Institute

\section{Source}

National Cancer Institute. Systolic Anterior Motion Indicator. NCI Thesaurus. Code C127593.

An indication as to whether there is systolic anterior motion of a cardiac cusp. 